\title{
Hydrozoan colonization and succession in the tidal and subtidal zones in Surtsey during the period 1967 to 1984
}

\author{
STEFFEN LUNDSTEEN ${ }^{\dagger}$, ERLINGUR HAUKSSON ${ }^{1}$ AND KARL GUNNARSSON ${ }^{2}$ \\ ${ }^{1}$ Fornistekkur 14, 109 Reykjavík, Iceland \\ ${ }^{2}$ Marine and Freshwater Research Institute, Skúlagata 4, 101 Reykjavík, Iceland \\ Address for correspondence: email: karl.gunnarsson@hafogvatn.is
}

\begin{abstract}
This article reports on results of investigations of hydrozoans collected in Surtsey, Iceland in the period 1967 - 1984. Samples were collected in the intertidal zone and by divers in the subtidal zone down to 40 $\mathrm{m}$. A list and illustrations of hydrozoan species found in the intertidal and subtidal rocky bottom in Surtsey are presented. Species numbers increased steadily during the study period and in 1984 a total of 37 species were recorded in Surtsey making hydrozoans one of the most diverse marine invertebrate groups in Surtsey. Among hydrozoans found during the study are 8 species not previously recorded in Iceland. Apart from dispersal by planktonic medusa, rafting of polyps on floating objects drifting to Surtsey is thought to be important for colonisation of hydrozoan fauna in Surtsey. At the end of the investigations period, 20 years after formation of rocky shores on the island, number of species seemed to be continually increasing.
\end{abstract}

\section{INTRODUCTION}

The island Surtsey $\left(63^{\circ} 18^{\prime} \mathrm{N}, 20^{\circ} 36^{\prime} \mathrm{W}\right)$ was born in a series of volcanic eruptions between 1963 and 1967. When the eruptions stopped in 1967 the island had reached $2.7 \mathrm{~km}^{2}$ in area. Since then the island has diminished considerably due to intensive erosion of the shoreline by heavy waves and now covers less than half its original size. The erosion of the shore has been most severe at the southwestern part of the island but slightest on the eastern side. (Jakobsson et al. 2000).

Surtsey is situated about $30 \mathrm{~km}$ off south coast of Iceland. The distance from Heimaey, the largest island in Vestmannaeyjar archipelago, is $20 \mathrm{~km}$ and about $3 \mathrm{~km}$ are from nearest rock rising above sea surface, Geirfuglasker.

\footnotetext{
$\dagger$ Steffen Lundsteen passed away in September 2018. Steffen was a marine biologist working at the Århus University, Denmark. Steffen was a skilled research diver with long experience in working with benthic biota. He joined Surtsey marine research in 1980 and took part in sampling, identified the hydrozoan species and made the illustrations that are presented in this paper. He passed away, way too soon, and we his co-authors (EH \& KG) remember him with gratitude for his friendship and collaboration.
} 
Monitoring colonisation and succession of benthic organisms started already 1964 in the intertidal zone a year after the eruption started and in 1968, divers started sampling in subtidal slopes of the Island. In the beginning studies were done every year but after 1971 intervals between samplings have become increasingly longer (Jónsson 1970, Jónsson et al. 1987, Sigurðsson 1999, 2000, Gunnarsson $\&$ Hauksson 2009). The studies have focused on hard substrate where macrofauna and -flora have developed. Most of the marine macrofaunal groups found in Surtsey has been reported on, in a series of articles by Sigurðsson $(1968,1970,1972,1974,1999$, 2000), Hauksson $(1982,1992,2000)$ and Gunnarsson \& Hauksson (2009). However, hydrozoans that are prominent element of the fauna on subtidal rocky substrate, have been largely omitted hitherto.

The first systematic studies of hydrozoan fauna of Iceland date from the beginning of $20^{\text {th }}$ century (Sæmundsson 1902, 1911). Sæmundsson (1911) registered 60 species of hydrozoans living at the Icelandic coast. Later, works of Broch $(1916,1918)$ and Kramp (1938) added to the list of hydrozoa known from Iceland and extending it to 90 species. Extensive sampling of benthic animals in Icelandic waters during the BIOICE program added significantly to knowledge of the hydrozoa fauna of Iceland its species and their distribution. Schuchert (2000, 2001), after analysing of the BIOICE material and revising older records, lists 129 species of hydrozoans found in Icelandic waters.

Here we present results of studies on the colonisation and succession of hydrozoans on rocky substrate in intertidal and shallow subtidal zone in Surtsey during the period from 1967 to 1984 . The paper is primarily based on species analysis by Steffen Lundsteen.

\section{MATERIAL AND METHODS}

Most of the intertidal coastline of Surtsey is covered by basaltic rocks or cliffs, except the northern part, which is of sand (Calles et al. 1982). In the subtidal zone, substrate off the northern part is sand, but along the east, south and the west it consists of boulders and large rocks in the shallow parts, but in the deeper parts sand becomes more common between rocks, and below $25 \mathrm{~m}$ sand covers large part of the bottom.

The sea around Surtsey is influenced by the North Atlantic current with salinity of 35.1 and surface temperatures that reach 12 to $13^{\circ} \mathrm{C}$ during late summer and falls to $6^{\circ} \mathrm{C}$ in winter (Marine and Freshwater Research Institute 2020). Visibility of the waters in the area is reduces by outflow of several large glacial rivers at the south coast of Iceland.

The material was collected in 1967, 1968, 1969, 1970, 1971, 1974, 1977, 1980 and 1984. The intertidal zone was sampled in the first three sampling years. Sampling of the subtidal zone started in 1968 and followed in all subsequent sampling years. Samples from the intertidal zone were collected during landing excursions on the coast. Samples from the subtidal were taken by divers at different depths at several stations around the island. Emphasis was on taking samples from all types of substrates and habitats. The sea conditions can be very rough at the island and sampling stations had to be chosen according to weather conditions, prevailing during sampling expeditions. The subtidal zone was sampled at depths between 5 to $40 \mathrm{~m}$. However, most of the samples were from $10 \mathrm{~m}$ to $30 \mathrm{~m}$. Faunal samples were preserved in $70 \%$ isopropanol for later examination. For further information about the sampling procedure see Sigurðsson (1968, 1970, 1972, and 1974) and Hauksson (1982 and 1992).

From the tidal belt 21 samples were examined and 113 samples from the subtidal zone. Samples were first sorted into higher taxonomic groups with hydrozoans grouped separately. Examination of hydrozoan samples and species identification was done under a stereo microscope with camera lucida as a drawing aid. Species occurrence in samples was recorded along with types of substrate on which hydrozoans were growing. Species names have been updated in accordance with the WoRMS database (2020). Authorities of scientific names of hydrozoan species mentioned in text are given in Table 2.

\section{RESULTS}

Hydrozoans were a prominent part of hard bottom faunal community that had developed in the subtidal zone in Surtsey (Fig. 1). The species with highest frequency, occurring in more than $40 \%$ of samples, during 3 of the latest sampling years were Bougainvillia muscus, Clytia gracilis, Diphasia rosacea, Ectopleura larynx, Halecium undulatum, Obelia geniculata, O. longissima and Phialella quadrata (Table 1).

Most of the species recorded had relatively wide depth distribution throughout the subtidal zone, although a few of the species that were first found 


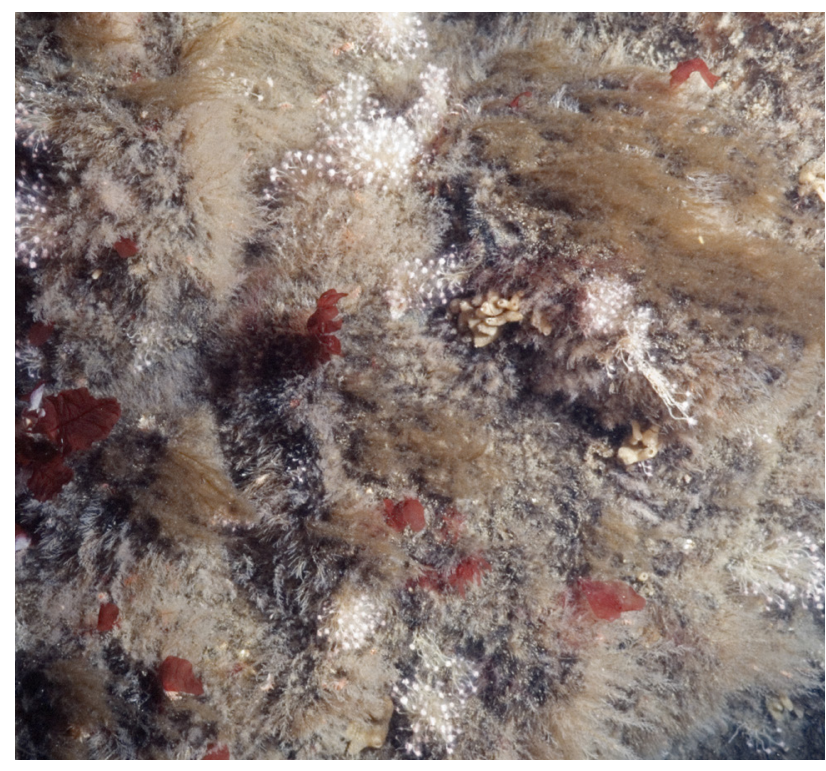

Figure 1. Hydrozoans are a prominent part of the hard bottom benthic fauna in the subtidal zone around Surtsey. Photo taken at $25 \mathrm{~m}$ depth in Surtsey in June 1984. at the end of the study period had only settled at 20 to $30 \mathrm{~m}$ depth (Table 1). In 1967 four species were found in the intertidal zone all of them were drift specimens attached to subtidal algae or stones cast ashore with other subtidal animals attached. All those 4 species have since been found every year growing in the subtidal zone (Table 2). In 1968 when direct sampling in the subtidal zone started, 10 species were found. Since then number of species found each sampling year have increased steadily (Fig. 2). In 1984, there were 27 species found in Surtsey. In total 37 hydrozoan species were registered in Surtsey, for the period $1967-1984$

Many of the species were missing in one or more sampling years after they were first found. It is quite likely in those cases that some of the smaller or the rarer once have been overlooked. Bigger and more prominent species are more likely to be found if present. The fact that they were absent in some of the sampling years but not others, indicates that they are opportunistic, appearing only when conditions

Table 1. Vertical and horizontal distribution of Hydrozoan species found in Surtsey in the year 1984. Species with the highest frequency of occurrence during the last three sampling years are marked with an asterix.

\begin{tabular}{|c|c|c|c|c|c|c|c|c|c|c|c|c|c|c|c|c|c|c|c|}
\hline & \multicolumn{2}{|c|}{ North-East } & \multicolumn{4}{|c|}{ East } & \multicolumn{5}{|c|}{ South-East } & \multicolumn{4}{|c|}{ South } & \multicolumn{4}{|c|}{ West } \\
\hline & $10 \mathrm{~m}$ & $15 \mathrm{~m}$ & $5 \mathrm{~m}$ & $10 \mathrm{~m}$ & $15 \mathrm{~m}$ & $30 \mathrm{~m}$ & $5 \mathrm{~m}$ & $10 \mathrm{~m}$ & $15 \mathrm{~m}$ & $20 \mathrm{~m}$ & $30 \mathrm{~m}$ & $10 \mathrm{~m}$ & $15 \mathrm{~m}$ & $20 \mathrm{~m}$ & $30 \mathrm{~m}$ & $10 \mathrm{~m}$ & $15 \mathrm{~m}$ & $20 \mathrm{~m}$ & $30 \mathrm{~m}$ \\
\hline Bougainvillia muscus* & & $\mathrm{x}$ & & & & $\mathrm{x}$ & & & & $\mathrm{x}$ & $\mathrm{x}$ & & & $\mathrm{x}$ & $\mathrm{x}$ & & $\mathrm{x}$ & $\mathrm{x}$ & $\mathrm{x}$ \\
\hline Calycella syringia & $\mathrm{x}$ & & & & & & & & & $\mathrm{x}$ & $\mathrm{x}$ & $\mathrm{x}$ & & & $\mathrm{x}$ & & & $\mathrm{x}$ & \\
\hline Campanulina pumila & $\mathrm{x}$ & $\mathrm{x}$ & $\mathrm{x}$ & & & & & & $\mathrm{x}$ & $\mathrm{x}$ & & & $\mathrm{x}$ & $\mathrm{x}$ & $\mathrm{x}$ & & $\mathrm{x}$ & $\mathrm{x}$ & \\
\hline Clytia gracilis & $\mathrm{x}$ & $\mathrm{x}$ & & & & & & & & $\mathrm{x}$ & & & $\mathrm{x}$ & $\mathrm{x}$ & $\mathrm{x}$ & & $\mathrm{x}$ & $\mathrm{x}$ & $\mathrm{x}$ \\
\hline Clytia hemisphaerica & $\mathrm{x}$ & & & & & & & & & & $\mathrm{x}$ & & & & & & & & \\
\hline Diphasia rosacea* & $\mathrm{x}$ & $\mathrm{x}$ & & $\mathrm{x}$ & & $\mathrm{x}$ & & & & $\mathrm{x}$ & $\mathrm{x}$ & & $\mathrm{x}$ & $\mathrm{x}$ & $\mathrm{x}$ & & $\mathrm{x}$ & $\mathrm{x}$ & $\mathrm{x}$ \\
\hline Ectopleura larynx* & $\mathrm{x}$ & $\mathrm{x}$ & & & $\mathrm{x}$ & $\mathrm{x}$ & & & $\mathrm{x}$ & $\mathrm{x}$ & $\mathrm{x}$ & & $\mathrm{x}$ & $\mathrm{x}$ & $\mathrm{x}$ & & & $\mathrm{x}$ & $\mathrm{x}$ \\
\hline Eudendrium arbuscula & & & & & & & & & & $\mathrm{x}$ & & & & & & & & & \\
\hline Eudendrium capillare & & & & & & & & & & & & & & & & & & & $\mathrm{x}$ \\
\hline Eudendrium rameum & & & & & & & & & & & $\mathrm{x}$ & & & & & & & & \\
\hline Filellum serpens & $\mathrm{x}$ & & & $\mathrm{x}$ & & & & & $\mathrm{x}$ & $\mathrm{x}$ & & & $\mathrm{x}$ & $\mathrm{x}$ & & & & & \\
\hline Gonothyraea loveni & & & & & & & $\mathrm{x}$ & & & & $\mathrm{x}$ & & & & & & & & \\
\hline Halecium beanii & & & & & & & & & & & $\mathrm{x}$ & & $\mathrm{x}$ & & & & & & \\
\hline Halecium curvicaule & $\mathrm{x}$ & & & & & $\mathrm{x}$ & & & & $\mathrm{x}$ & $\mathrm{x}$ & & & $\mathrm{x}$ & & & $\mathrm{x}$ & & \\
\hline Halecium muricatum & & & & & & & & & & & $\mathrm{x}$ & & & & & & & & \\
\hline Halecium undulatum* & $\mathrm{x}$ & & & & & & $\mathrm{x}$ & & & $\mathrm{x}$ & $\mathrm{x}$ & & $\mathrm{x}$ & $\mathrm{x}$ & & & $\mathrm{x}$ & $\mathrm{x}$ & $\mathrm{x}$ \\
\hline Lafoeina tenuis & $\mathrm{x}$ & & & & & & & & & $\mathrm{x}$ & & & & $\mathrm{x}$ & & & & $\mathrm{x}$ & \\
\hline $\begin{array}{l}\text { Mitrocomella } \\
\text { polydiademata }\end{array}$ & & & & & & & & & & $\mathrm{x}$ & & & & & & & & & \\
\hline Obelia dichotoma & & $\mathrm{x}$ & & $\mathrm{x}$ & $\mathrm{x}$ & & $\mathrm{x}$ & & & $\mathrm{x}$ & $\mathrm{x}$ & & & & & & & & \\
\hline Obelia geniculata* & $\mathrm{x}$ & $\mathrm{x}$ & $\mathrm{x}$ & $\mathrm{x}$ & $\mathrm{x}$ & $\mathrm{x}$ & $\mathrm{x}$ & $\mathrm{x}$ & $\mathrm{x}$ & $\mathrm{x}$ & $\mathrm{x}$ & $\mathrm{x}$ & $\mathrm{x}$ & $\mathrm{x}$ & & $\mathrm{x}$ & $\mathrm{x}$ & & $\mathrm{x}$ \\
\hline Obelia hyalina & & & & & & & & & & & $\mathrm{x}$ & & & & & & & & \\
\hline Obelia longissima* & $\mathrm{x}$ & $\mathrm{x}$ & $\mathrm{x}$ & & & $\mathrm{x}$ & $\mathrm{x}$ & & $\mathrm{x}$ & $\mathrm{x}$ & $\mathrm{x}$ & & $\mathrm{x}$ & $\mathrm{x}$ & $\mathrm{x}$ & & $\mathrm{x}$ & $\mathrm{x}$ & $\mathrm{x}$ \\
\hline Orthopyxis integra & $\mathrm{x}$ & & & $\mathrm{x}$ & & & & & $\mathrm{x}$ & $\mathrm{x}$ & & & & $\mathrm{x}$ & & & $\mathrm{x}$ & & \\
\hline Phialella quadrata* & & $\mathrm{x}$ & & & & & & & & $\mathrm{x}$ & $\mathrm{x}$ & & $\mathrm{x}$ & $\mathrm{x}$ & $\mathrm{x}$ & $\mathrm{x}$ & & & $\mathrm{x}$ \\
\hline Podocoryna carnea & & & & & & & & & & $\mathrm{x}$ & & & & & & & & & \\
\hline Sarsia lovenii & & & & & & & & & & $\mathrm{x}$ & & & & & & & & & \\
\hline Sarsia tubulosa & & & & & & & & & & & $\mathrm{x}$ & & & & & & & $\mathrm{x}$ & $\mathrm{x}$ \\
\hline Zanclea implexa & & & & & & & & & & & $\mathrm{x}$ & & & & & & & & $\mathrm{x}$ \\
\hline
\end{tabular}


Table 2. Order of arrival of hydrozoan species in Surtsey from the beginning of colonisation until 1984. Species not recorded in Iceland before are marked with asterix.

\begin{tabular}{|c|c|c|c|c|c|c|c|c|c|}
\hline Species & 1967 & 1968 & 1969 & 1970 & 1971 & 1974 & 1977 & 1980 & 1984 \\
\hline Ectopleura larynx (Ellis \& Solander, 1786) & $\mathrm{x}$ & $\mathrm{x}$ & $\mathrm{x}$ & $\mathrm{x}$ & $\mathrm{x}$ & $\mathrm{x}$ & $\mathrm{x}$ & $\mathrm{x}$ & $\mathrm{x}$ \\
\hline Obelia geniculata (Linnaeus, 1758) & $\mathrm{x}$ & $\mathrm{x}$ & $\mathrm{x}$ & $\mathrm{x}$ & $\mathrm{x}$ & $\mathrm{x}$ & $\mathrm{x}$ & $\mathrm{x}$ & $\mathrm{x}$ \\
\hline Obelia longissima (Pallas, 1766) & $\mathrm{x}$ & $\mathrm{x}$ & $\mathrm{x}$ & $\mathrm{x}$ & $\mathrm{x}$ & $\mathrm{x}$ & $\mathrm{x}$ & $\mathrm{x}$ & $\mathrm{x}$ \\
\hline Phialella quadrata (Forbes, 1848)* & $\mathrm{x}$ & $\mathrm{x}$ & $\mathrm{x}$ & $\mathrm{x}$ & $\mathrm{x}$ & $\mathrm{x}$ & $\mathrm{x}$ & $\mathrm{x}$ & $\mathrm{x}$ \\
\hline Bougainvillia muscus (Allman, 1863) & & $\mathrm{x}$ & $\mathrm{x}$ & $\mathrm{x}$ & $\mathrm{x}$ & $\mathrm{x}$ & $\mathrm{x}$ & $\mathrm{x}$ & $\mathrm{x}$ \\
\hline Diphasia rosacea (Linnaeus, 1758) & & $\mathrm{x}$ & & & $\mathrm{x}$ & $\mathrm{x}$ & $\mathrm{x}$ & $\mathrm{x}$ & $\mathrm{x}$ \\
\hline Clytia hemisphaerica (Linnaeus, 1767) & & $\mathrm{x}$ & & & & $\mathrm{x}$ & $\mathrm{x}$ & $\mathrm{x}$ & $\mathrm{x}$ \\
\hline Lafoeina tenuis Sars, $1874 *$ & & $\mathrm{x}$ & & $\mathrm{x}$ & $\mathrm{x}$ & & & $\mathrm{x}$ & $\mathrm{x}$ \\
\hline Obelia dichotoma (Linnaeus, 1758) & & $\mathrm{x}$ & & $\mathrm{x}$ & & $\mathrm{x}$ & $\mathrm{x}$ & $\mathrm{x}$ & $\mathrm{x}$ \\
\hline Corymorpha nutans M. Sars, 1835 & & $\mathrm{x}$ & & & & & & & \\
\hline Calycella syringa (Linnaeus, 1767) & & & $\mathrm{x}$ & $\mathrm{x}$ & $\mathrm{x}$ & $\mathrm{x}$ & $\mathrm{x}$ & $\mathrm{x}$ & $\mathrm{x}$ \\
\hline Eudendrium rameum (Pallas, 1766) & & & $\mathrm{x}$ & $\mathrm{x}$ & $\mathrm{x}$ & $\mathrm{x}$ & $\mathrm{x}$ & $\mathrm{x}$ & $\mathrm{x}$ \\
\hline Podocoryna carnea M. Sars, 1846 & & & $\mathrm{x}$ & $\mathrm{x}$ & $\mathrm{x}$ & & $\mathrm{x}$ & $\mathrm{x}$ & \\
\hline Clytia gracilis (M. Sars, 1850) & & & & $\mathrm{x}$ & $\mathrm{x}$ & $\mathrm{x}$ & $\mathrm{x}$ & $\mathrm{x}$ & $\mathrm{x}$ \\
\hline Orthopyxis integra (MacGillivray, 1842) & & & & $\mathrm{x}$ & $\mathrm{x}$ & $\mathrm{x}$ & $\mathrm{x}$ & $\mathrm{x}$ & $\mathrm{x}$ \\
\hline Halecium curvicaule Lorenz, 1886 & & & & $\mathrm{x}$ & $\mathrm{x}$ & $\mathrm{x}$ & $\mathrm{x}$ & $\mathrm{x}$ & $\mathrm{x}$ \\
\hline Aequorea forskalea Péron \& Lesueur, 1810 & & & & $\mathrm{x}$ & & & & & \\
\hline Halecium labrosum Alder, 1859 & & & & & $\mathrm{x}$ & $\mathrm{x}$ & $\mathrm{x}$ & & \\
\hline Cuspidella humilis Hincks, 1866 & & & & & $\mathrm{x}$ & & & & \\
\hline Filellum serpens (Hassall, 1848) & & & & & & $\mathrm{x}$ & $\mathrm{x}$ & $\mathrm{x}$ & $\mathrm{x}$ \\
\hline Rhizorhagium roseum M. Sars, 1874 & & & & & & $\mathrm{x}$ & $\mathrm{x}$ & $\mathrm{x}$ & \\
\hline Halecium muricatum (Ellis \& Solander, 1786) & & & & & & $\mathrm{x}$ & $\mathrm{x}$ & & $\mathrm{x}$ \\
\hline Eudendrium capillare Alder, 1856* & & & & & & & $\mathrm{x}$ & & $\mathrm{x}$ \\
\hline Halecium halecinum (Linnaeus, 1758) & & & & & & & $\mathrm{x}$ & & \\
\hline Hydrallmania falcata (Linnaeus, 1758) & & & & & & & & $\mathrm{x}$ & \\
\hline Opercularella lacerata (Johnston, 1847) & & & & & & & & $\mathrm{x}$ & \\
\hline Tiaropsis multicirrata (M. Sars, 1835)* & & & & & & & & $\mathrm{x}$ & \\
\hline Campanulina pumila (Clark, 1875) & & & & & & & & $\mathrm{x}$ & $\mathrm{x}$ \\
\hline Eudendrium arbuscula Wright, 1859* & & & & & & & & $\mathrm{x}$ & $\mathrm{x}$ \\
\hline Gonothyraea loveni (Allman, 1859) & & & & & & & & $\mathrm{x}$ & $\mathrm{x}$ \\
\hline Halecium undulatum Billard, 1921 & & & & & & & & $\mathrm{x}$ & $\mathrm{x}$ \\
\hline Zanclea implexa (Alder, 1856)* & & & & & & & & $\mathrm{x}$ & $\mathrm{x}$ \\
\hline Halecium beanii (Johnston, 1838) & & & & & & & & & $\mathrm{x}$ \\
\hline Eudendrium ramosum (Linnaeus, 1758) & & & & & & & & & $\mathrm{x}$ \\
\hline Mitrocomella polydiademata (Romanes, 1876)* & & & & & & & & & $\mathrm{x}$ \\
\hline Sarsia lovenii (M. Sars, 1846)* & & & & & & & & & $\mathrm{x}$ \\
\hline Sarsia tubulosa (M. Sars, 1835) & & & & & & & & & $\mathrm{x}$ \\
\hline
\end{tabular}

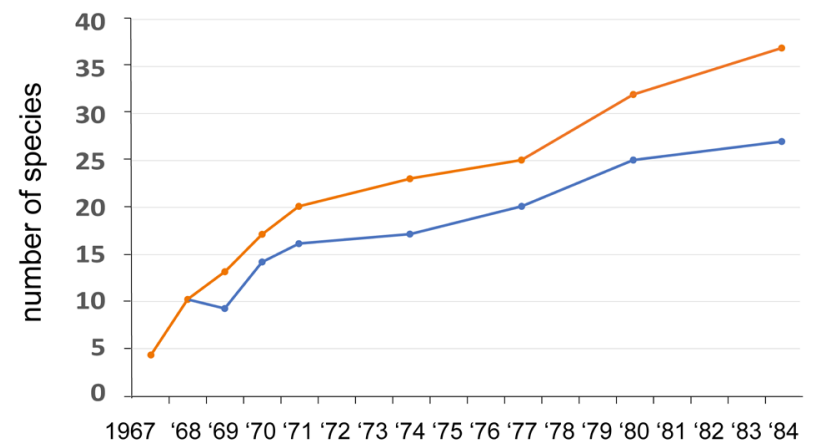

Figure 2. Changes in number of hydrozoan species registered in Surtsey during the period 1967 to 1984 . Blue curve: number of species found each sampling year. Orange curve: cumulative number of species recorded in Surtsey. are favourable or substrate freely available. Most species did not appear to be substrate specific and were alternatively found growing on stones, shells or other hydrozoans. Exceptions are Ectopleura larynx that was rarely found on other substrate than rocks, Filellum serpens was only found on other hydrozoans, Obelia geniculata was mostly found attached to algae and Corymorpha nutans was found growing in sand.

Eleven species were detected in all the subsequent sampling years since they were first found, for at least four sampling years. Those are Bougainvillia muscus, Calycella syringia, Clytia gracilis, Ectopleura larynx, Eudendrium rameum (Fig. 6), Filellum serpens, Halecium curvicaule, Obelia geniculata, 
O. longissima, Orthopyxis integra and Phialella quadrata. Additionally, Clytia haemispherica, Diphasia rosacea and Obelia dichotoma were found consistently in the last 4 to 5 sampling years (Table 1) although originally found earlier.

Eight of the species found in Surtsey had not been recorded for Iceland before (cf. Schuchert 2001). Those are the following:

1. Aequorea forskalea Péron \& Lesueur, 1810; Hydroid stage referred to this specie was found in Surtsey in 1970 at $40 \mathrm{~m}$ depth growing on a Mytilus edulis shell.

2. Eudendrium arbuscula Wright, 1859 (Fig. 3); Fertile colonies of this species were found in Surtsey in August 20, 1971 at $20 \mathrm{~m}$ depth. It was found again, in 1980, attached to a stipe of the kelp Laminaria hyperborea, and in 1984 on calcareous plates of a Balanus sp.

3. Lafoeina tenuis Sars, 1874; First found in 1968

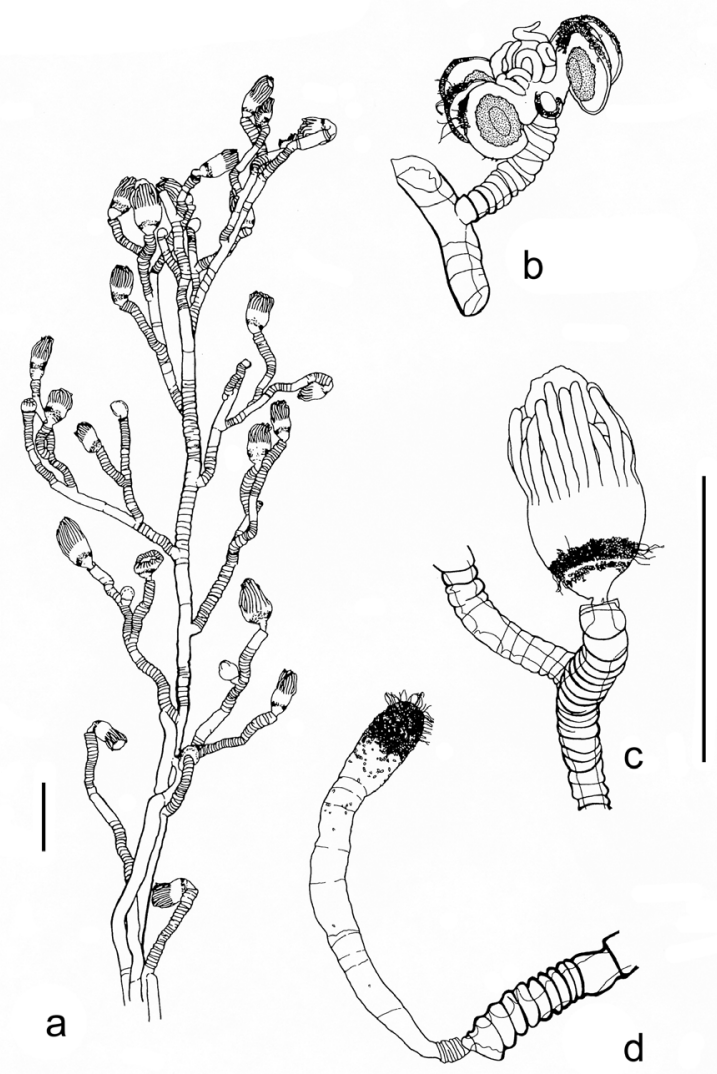

Figure 3. Eudendrium arbuscula Wright, 1859. Surtsey West coast 20.08.1971 at $20 \mathrm{~m}$ depth. a, habitus of a colony; b, hydranth with female gonophores, note terminal button with nematocysts; $\mathbf{c}$, feeding hydranth with a basal band of nematocyst; $\mathbf{d}$, nematophore with nematocysts covering its apex. Scale bars; 1 $\mathrm{mm}$, for $\boldsymbol{a}$ on the left side and for $\boldsymbol{b}, \boldsymbol{c}$ and $\boldsymbol{d}$ on right side. and subsequently in 1970, 1971, 1980 and 1984, growing on shells of Mytilus edulis and on other hydrozoans.

4. Mitrocomella polydiademata (Romanes, 1876); Found in 1984 at $20 \mathrm{~m}$ depth, growing on stolons of Obelia longissima (cf. Cornelius 1995, Schuchert 2001 regarding identification of M. polydiademata).

5. Phialella quadrata (Forbes, 1848); This species was first found in Surtsey 1967 in the intertidal zone on stone cast ashore and was since found in all sampling years at depths from 5 to $40 \mathrm{~m}$. It was a common species in Surtsey and was found growing mostly on other hydrozoans but also on shells, stones and occasionally on algae.

6. Sarsia lovenii (M. Sars, 1846); Found in 1984 at $20 \mathrm{~m}$ depth growing on stone.

7. Tiaropsis multicirrata (M. Sars, 1835); First found in 1980 at $15 \mathrm{~m}$ depth, growing on stone.

8. Zanclea implexa (Alder, 1856) (Fig. 4); First found in 1980 growing at 25 and $30 \mathrm{~m}$ depth on shells of Heteranomia squamula (Linnaeus, 1758).

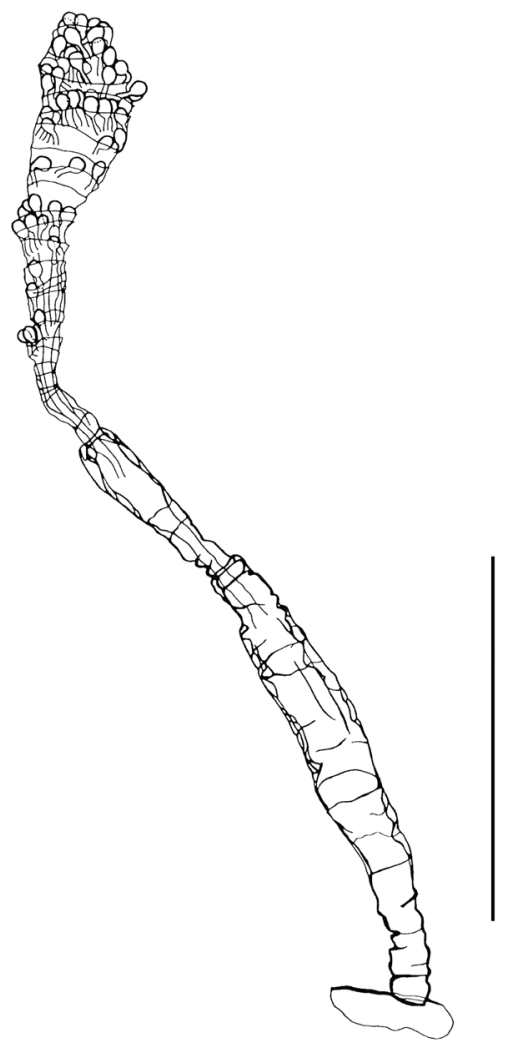

Figure 4. Zanclea implexa (Alder, 1856). Surtsey West coast, 29.07.1980, at $30 \mathrm{~m}$ depth. A specimen with single hydranth having capitate tentacles. Scale bar; $1 \mathrm{~mm}$. 


\section{DISCUSSION}

The number of hydrozoa species found in Surtsey increased rapidly from the start of the observations in 1967 until about 1971 when 19 species were found (Fig. 1), some of which are illustrated here for taxonomic clarity (Figs 3-8). Since then the increase in number of species recorded slowed down and at the end of the observation period in 1984, 37 species had been found. Previously 129 hydrozoa species have been recorded from Iceland (Schuchert 2001). Additional 8 species were recorded during the present study. The hydrozoan fauna of Surtsey makes up a relatively high percentage of the hydrozoan fauna of Iceland, or about $27 \%$. A high percentage considering that a large part of the species previously recorded in Icelandic waters are deep water species that one would not expect to find in shallow waters as studied here (Schuchert 2001).

Hydrozoans are one of the most diverse groups of the faunal community in Surtsey. Their importance in terms of cover of rocky substrate is least at shallower depths where seaweed species dominate. In deeper waters, their coverage increases and below $20 \mathrm{~m}$ depth hydrozoans cover more than $50 \%$ of the hard substrate (Gunnarsson \& Hauksson 2009).

High abundance of Bougainvillia muscus in Surtsey is unexpected. Previously only one colony of this species has been reported from southern Iceland

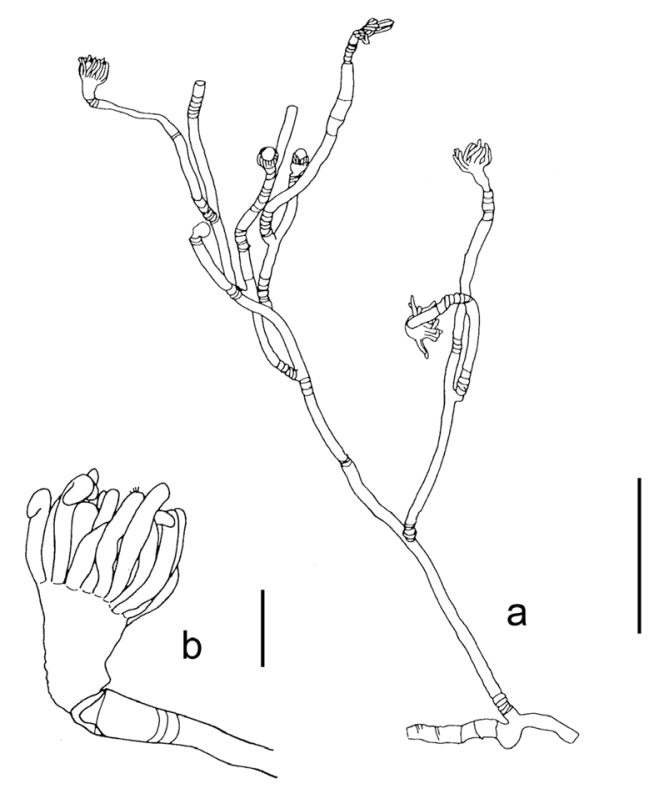

Figure 5. Eudendrium capillare Alder, 1856. Surtsey South coast, 11.07.1977, $20 \mathrm{~m}$ depth. a, habitus of a colony; b, details of a feeding hydranth. Scale bars; a $1 \mathrm{~mm}$, b: $0.1 \mathrm{~mm}$.

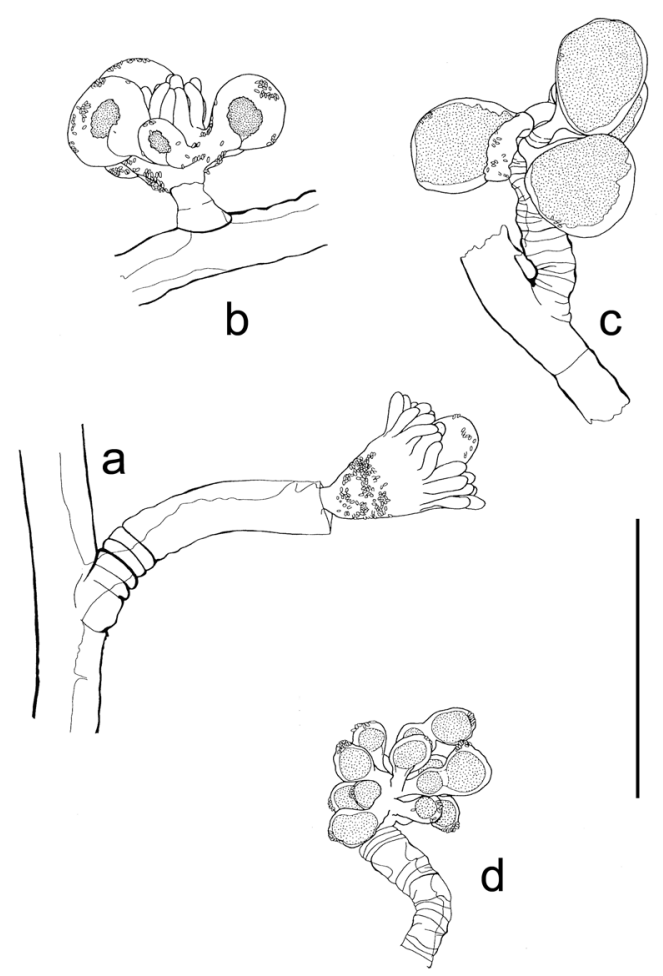

Figure 6. Eudendrium rameum (Pallas, 1766). Surtsey NorthWest coast, 26.07 1969, 28 - $30 \mathrm{~m}$ depth. a, feeding hydranth with nematocysts spread at its lower part; b, c, female gonophores with spread nematocysts; $\mathbf{d}$, male gonophores with small patches of apical nematocysts. Scale bar: $1 \mathrm{~mm}$

(Kramp 1938). Its early establishment and abundance in Surtsey, might have been facilitated by large open spaces available for colonisation. On the other hand, the conspicuous species Tubularia indvisa, was not found in Surtsey, though this was to be expected as it is present at nearby shores and is probably common there (Sæmundsson 1911; Kramp 1938).

The life cycle of the hydrozoans is typically characterized by the alternation of three stages: benthic polyp stage, planktonic medusa and planula (Boero et al. 2002, Cornelius 2002). Dispersal can occur by planktonic medusa or planula drifting with currents or by rafting of the polyp stage attached to natural or anthropogenic, floating objects drifting at the surface of the sea. Planula are commonly produced, but usually only last a few hours. It is therefore unlikely that planula stage has any significance in dispersal of hydrozoans to Surtsey. The medusae live stages last from a few hours up to a month (Bouillon et al. 2004). Only some of the species found in Surtsey have an independent medusa stage, which lasts for several days, and could therefore contribute to their dispersal to the island. 


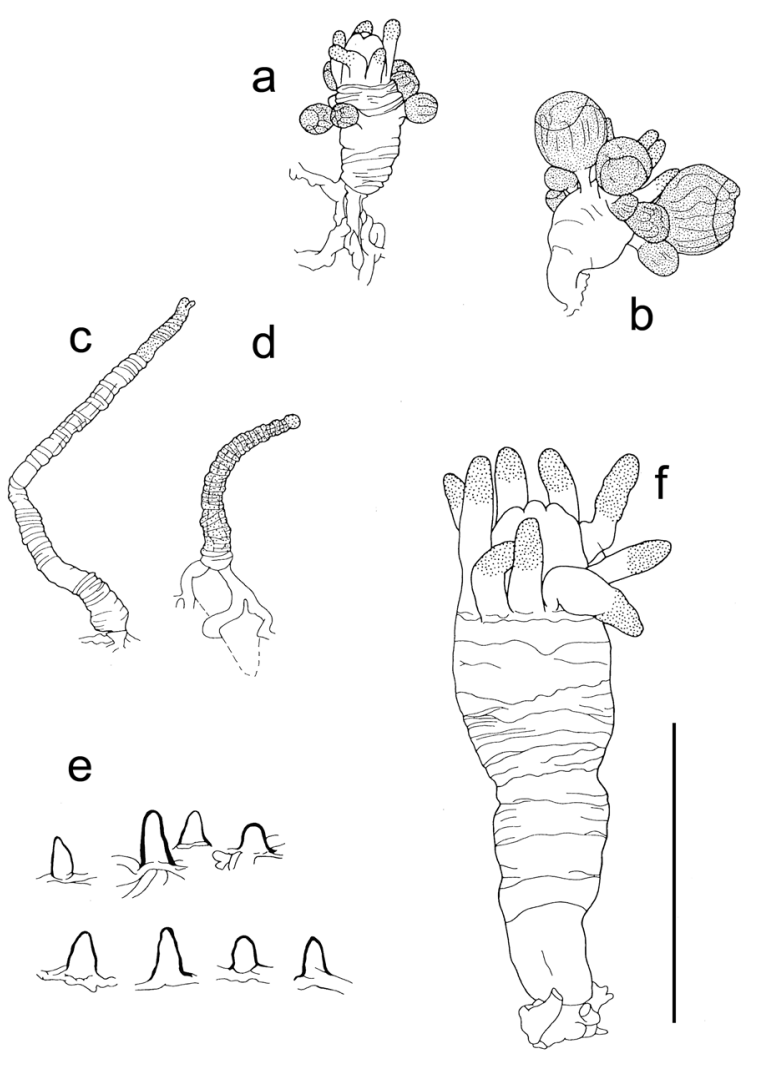

Figure 7. Podocoryna carnea M. Sars, 1846. Surtsey East coast, 09.07.1977, 20 m depth. a, b, hydranths bearing medusa buds; c, d, dactylozoids; e, spines of hydrorhiza; f, solidary feeding hydranth. Scale bar: $1 \mathrm{~mm}$.

Rafting probably plays an important role in the dispersal of hydrozoa species to Surtsey. Natural derived rafts such as drifting seaweeds, vegetation turfs, tree branches and driftwood have been found stranded on the shores of Surtsey. In addition, flotsam, plastic floats, bottles and other floating anthropogenic objects are regularly found cast ashore. Ingólfsson (1995) considers rafting on clumps of seaweed an important factor in the dispersal of marine intertidal fauna and has hypothesised that rafting might have been the main factor for benthic fauna repopulating the shores of Iceland and the Canadian Maritime after the last glacial maximum (Ingólfsson 1992).

Hydrozoans are amongst the most common epizoic fauna on rafts drifting in the Oceans (Tiel $\&$ Gutow 2005). The tsunami event that occurred 2011 in Japan resulted in large-scale wrecking of maritime structures. This left great amount of debris floating in the ocean, substantial part of which was transported by currents across the Pacific to the west coast of North America. These structures supported diverse fauna that was carried along across the ocean

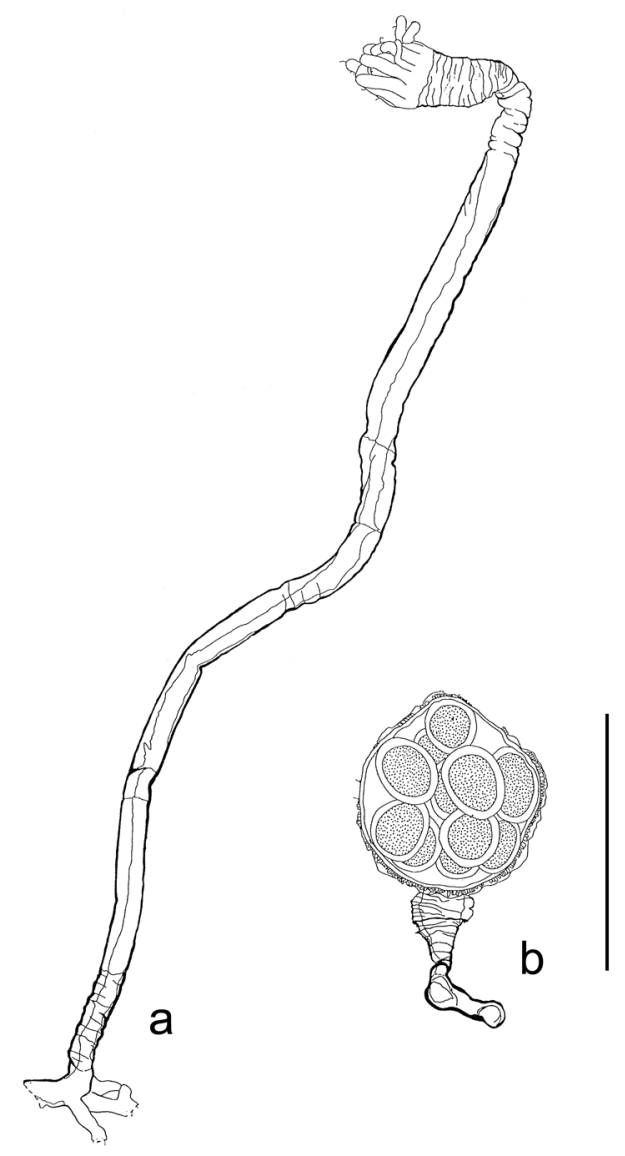

Figure 8. Rhizorhagium roseum M. Sars, 1874. Surtsey W, 10.07.1977, $10 \mathrm{~m}$ depth. a, habitus of a specimen with a single hydranth, b, sporosac with eggs. Scale bar: $1 \mathrm{~mm}$.

(Carlton et al. 2017). Among the most diverse of the attached organisms were hydrozoans (Choon et al. 2018).

Significant changes were observed in the development of hydrozoan fauna in Surtsey during the study period. Species numbers were steadily rising, and frequency of the species changed. At the end of the study period in 1984 species were still being added to the hydrozoan fauna of Surtsey, 20 years after formation of rocky shores. Continued studies of hydrozoan sampled in Surtsey along with studies of the fauna attached to floating objects that drift to Surtsey will further help elucidate mode of arrival and the development of the hydrozoan fauna in Surtsey.

\section{ACKNOWLEDGEMENTS}

Financial support came from Icelandic Fisheries Fund, Icelandic Research Fund, Icelandic Democracy Fund and Danish National Research Foundation. We are grateful to the crew and divers on mb Sæör, rv 
Árni Friðriksson and rv Bjarni Sæmundsson for their assistance during sampling expeditions. Thanks, are due to Kay W. Petersen, Zoologisk Laboratorium in Copenhagen, for assistance with identification of hydrozoans and to Svanhildur Egilsdóttir, Marine and Freshwater Research Institute, Iceland for editing figures. We are also grateful to Guðmundur Guðmundsson Institute of Natural History, Iceland for useful comments on an earlier draft of the manuscript.

\section{REFERENCES}

Boero, F., Bouillon, J., Piraino, S. \& Schmid, V. 2002. Asexual reproduction in the Hydrozoa (Cnidaria). In R.N. Hughes (ed.). Reproductive biology of invertebrates. Vol. XI. Progress in asexual reproduction. Oxford \& IBH Publishing Co. Pvt. Ltd., New Delhi. pp. 141-158.

Bouillon, J., Medel, M.D., Pages, F., Gili, J.M., Boero, F. \& Gravili, C. 2004. Fauna of the Mediterranean Hydrozoa. Sci. Mar. 68, 5-438.

Broch, H. 1916. Hydroida. Part 1. Danish Ingolf-Expedition 5, part 6, $66 \mathrm{pp}$.

Broch, H. 1918. Hydroida, Part II. Danish Ingolf-Expedition 5, part 7, $200 \mathrm{pp}$.

Calles, B., Lindé, K. \& Norrman, J.O. 1982. The geomorphology of Surtsey island in 1980. Surtsey Research Progress Report $9,117-132$.

Carlton, J.T., Chapman, J.W., Geller, J.B., Miller, J.A., Carlton, D.A., McCuller, M.I., Treneman, N.C., Steves, B.P. \& Ruiz, G.M. 2017. Tsunami-driven rafting: Transoceanic species dispersal and implications for marine biogeography. Science 357, 1402-1406.

Choong, H.H.C., Calder, D.R., Chapman, J.W., Miller, J.A., Geller, J.B. \& Carlton, J.T. 2018. Hydroids (Cnidaria: Hydrozoa: Leptothecata and Limnomedusae) on 2011 Japanese tsunami marine debris landing in North America and Hawai'i, with revisory notes on Hydrodendron Hincks, 1874 and a diagnosis of Plumaleciidae, new family. Aquatic Invasions $13,43-70$

Cornelius, P.F.S. 1992. Medusa loss in leptolid Hydrozoa (Cnidaria), hydroid rafting, and abbreviated life-cycles among their remote-island faunae: an interim review. In: J. Bouillon, F. Boero, F. Cicocna, I.M. Gili \& R.G. Hughes (eds). Aspects of Hydrozoan Biology. Sci. Mar. 56(2-3), 245-261.

Cornelius, P.F.S. 1995. North-West European Thecate Hydroids and their Medusa. Part 1. In: R.S.K. Barnes \& H. Crother (eds). Synopsis of the British Fauna (New Series) No 50. Field Studies Council, Shrewsbury i-vii, 1-437.

Gunnarsson, K. \& Hauksson, E. 2009. Succession and benthic community development in the sublittoral zone at the recent volcanic island, Surtsey, southern Iceland. Surtsey Research 12, 161-166.

Hauksson, E. 1982. A survey of the subtidal fauna of Surtsey in 1974. Surtsey Research Progress Report 9, 59-61.

Hauksson, E. 1992. Studies of the subtidal fauna of Surtsey in 1980-1987 and changes in subtidal fauna from 1964 to 1987. Surtsey Research Progress Report 10, 33-42.

Hauksson, E. 2000. A survey of the benthic coastal fauna of Surtsey, Iceland, in 1997. Surtsey Research 11, 85-88.

Ingólfsson, A. 1992. The origin of the rocky shore fauna of Iceland and the Canadian Maritimes. Journal of Biogeography 19, 705-712.

Ingólfsson, A. 1995. Floating clumps of seaweed around Iceland: natural microcosms and a means of dispersal for shore fauna. Mar. Biol. 122, 13-21.

Jakobsson, S.P., Guðmundsson, G. \& Moore, J.G. 2000. Geological monitoring of Surtsey, Iceland, 1967-1998. Surtsey Research 11, 99-108.

Jónsson, S. 1970. Meeresalgen als erstbesiedler der vulkaninsel Surtsey. Schr. Naturv. Ver. Schlesv. -Holst. Sonderband, 21-28.

Jónsson, S., Gunnarsson, K. \& Briane, J.-P. 1987. Évolution de la nouvelle flore marine de l'île volcanique de Surtsey, Islande. Journal of the Marine Research Institute, Reykjavik 10(1), $1-30$.

Kramp, P.L. 1938. Marine Hydrozoa. Hydroida. Zoology of Iceland 2(5a), 1-82.

Marine and Freshwater Research Institute 2020. Sea surface temperatures at the Icelandic coast. http://www.hafro.is/Sjora/, searched on 16 March 2020.

Schuchert, P. 2000. Hydrozoa (Cnidaria) of Iceland collected by the BIOICE programme. Sarsia 85, 411-418.

Schuchert, P. 2001. Hydroids of Greenland and Iceland (Cnidaria, Hydrozoa). Meddelelser om Grönland, Bioscience 53. Copenhagen, The Danish Polar Center 2001, 184 pp.

Sigurðsson, A. 1968. The coastal invertebrate fauna of Surtsey and Vestmannaeyjar. Surtsey Research Progress Report 4, 95107.

Sigurðsson, A. 1970. The benthonic coastal fauna of Surtsey in 1968. Surtsey Research Progress Report 5, 70-77.

Sigurðsson, A. 1972. The benthic coastal fauna of Surtsey in 1969. Surtsey Research Progress Report 6, 91-96.

Sigurðsson, A. 1974. Report on the sampling of the benthic fauna of Surtsey 1970, 1971 and 1974. Surtsey Research Progress Report 7, 20-21.

Sigurðsson, A. 1999. Botndýr við Surtsey. Náttúrufræðingurinn 68(3-4), 201-207.

Sigurðsson, A. 2000. A survey of the benthic coastal fauna of Surtsey in 1992 and comparison with earlier data. Surtsey Research 11, 75-83.

Sæmundsson, B. 1902. Bidrag til Kundskaben om de 
islandske Hydroider. Videnskabelige Meddelelser fra Dansk Naturhistorisk Forening i København 1902, 47-74, plates 1-2. Sæmundsson, B. 1911. Bidrag til Kundskaben om de islandske Hydroider. II. - Videnskabelige Meddelelser fra Dansk Naturhistorisk Forening i København 63, 67-107.

Tiel, M. \& Gutow, L. 2005. The ecology of rafting in the marine environment. II. The rafting organisms and communities. Oceanography and Marine Biology, Annual Review 43, 279418.

WoRMS (2020). Hydrozoa. Accessed at: http://www. marinespecies.org/aphia.php? $\mathrm{p}=$ taxdetails $\& \mathrm{id}=1337$ on 2020 $03-26$. 